\begin{tabular}{l}
$\begin{array}{c}\text { Yanbu Journal } \\
\text { of }\end{array}$ \\
$\begin{array}{l}\text { Engineering } \\
\text { and Science }\end{array}$ \\
\hline \hline ISSN: $1658-5321$
\end{tabular}$\quad$ Vol. 8, April $2014(1435 \mathrm{H})$

\title{
SPECTROPHOTOMETRIC DETERMINATION OF HEXAVALENT CHROMIUM CONTENT IN COMMERCIAL CEMENT SAMPLES BY A SIMPLE AND RAPID PROCEDURE FOR THE EXTRACTION AND ANALYSIS OF CHROMIUM (VI)
}

\author{
Krasimira A. Stancheva ${ }^{1}$, Chand Pasha ${ }^{2}$ \\ 1 Department of Inorganic and Analytical Chemistry, Professor Dr. Assen Zlatarov University, \\ Bourgas 8010, Bulgaria \\ 2 Department of General Studies, Yanbu Industrial College, P. O. Box-30436, \\ Yanbu - 21477, Kingdom of Saudi Arabia \\ 2 Corresponding author E-mail: drcpasha@gmail.com
}

\begin{abstract}
A simple and rapid procedure for the extraction and analysis of chromium by spectrophotometric method has been developed. Throughout the world the content of hexavalent chromium in cement is under control. In Europe, the new restrictions on the amount of this substance prohibit the use of cement having concentration more than 2 ppm. However, hexavalent chromium contents in cements above $2 \mathrm{mg} \mathrm{kg}^{-1}$ are still found frequently. The study represents a contribution to the establishing of possible limitations of this compound. The analyses showed that 7 of 10 cement samples analyzed by us satisfy the requirements for limit value of $2 \mathrm{ppm}$ for water-soluble chromium (VI) in cement available in our market. Chromium (VI) was analyzed using the reference diphenylcarbazide spectrophotometric method from TRGS 613. The results for the absorbance spectra showed that maximum absorbance peak of the hexavalent chromium complex was at $538.7 \mathrm{~nm}$. It was recorded in the range $25-200 \mu \mathrm{g} \mathrm{Cr}(\mathrm{VI}) \mathrm{L}^{-1}$ using Varian Cary 50 reader system. This study presents a new procedure for chromium extraction. Parameters such as extraction time in dependence of the rotary of the stirring and wavelength variation were optimized and the results obtained were satisfying.

In the present work a cement sample from the Devnya manufacturer was tested and it was found that this cement satisfies the European standard requirements. Finally, this application describes a simple and rapid, cost-effective analysis to measure low levels of hexavalent chromium.
\end{abstract}

Keywords: Hexavalent chromium in cement, Spectrophotometric determination.

\section{INTRODUCTION}

Hexavalent chromium is one of the most widespread toxic environmental pollutants, which is inevitably present in building materials such as cement and concrete [1]. Hexavalent chromium is known human carcinogen and mutagen [2-8]. Cement producers are required to control the content of chromium (VI) in various types of production. From January 17th, 2005 in Europe new restrictions on the amount of chromium (VI) in cement came into force by the Directive 2003/53/EC [9]. The airs and soils around cement industries have been more polluted than before, since cement industries have used diverse wastes as fuels and side-raw materials in cement 
production [10]. Water soluble chromium in cement is limited to $2 \mathrm{mgkg}^{-1}$ in European standards.

The restriction is applied to a wide range of products such as mortars, grouts, tile adhesives etc. [2-4]. The construction trade cooperative, health agencies, and cement industries adopted the "Low chromate cement and formulations" trade regulation.

\subsection{HEXAVALENT CHROMIUM IN CEMENT}

Chromium is a naturally occurring element in the natural environment in rocks, animal and plant species, soil, volcanic dust and gases. High levels of chromium are found in minerals such as chromite. Elevated concentrations of chromium (VI) in the environment are the result of industrial pollution.

Trace element chromium exists as raw materials mainly used for cement production. Its content is mainly in the form of chromium (III), which is inert and insoluble, but during the course of treatment, chromium (III) can be partially oxidized to $\mathrm{Cr}$ (VI).

Chromium(VI) compounds are powerful oxidants (Fig. 1) and except the hexafluoride, contain oxygen as a ligand, such as the chromate anion $\left(\mathrm{CrO}_{4}{ }^{2-}\right)$ and chromyl chloride $\left(\mathrm{CrO}_{2} \mathrm{Cl}_{2}\right) \quad$ [8]. Chromium compounds have never been deliberately added to cement, except in China to save time, hence the cost of production [11].

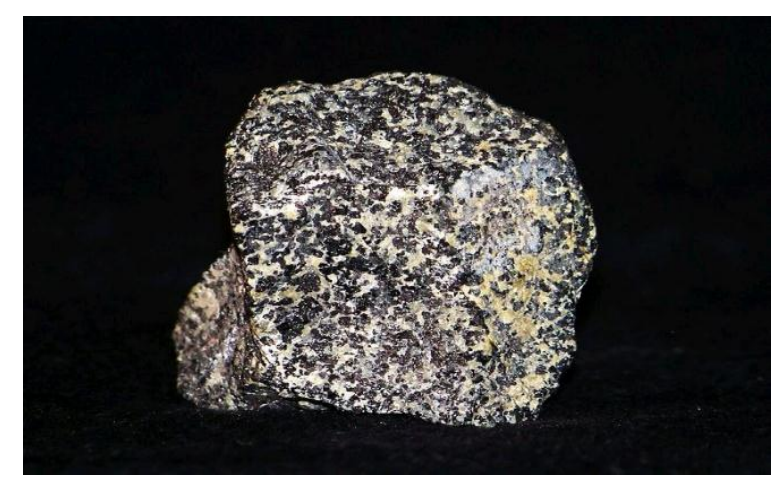

(a)

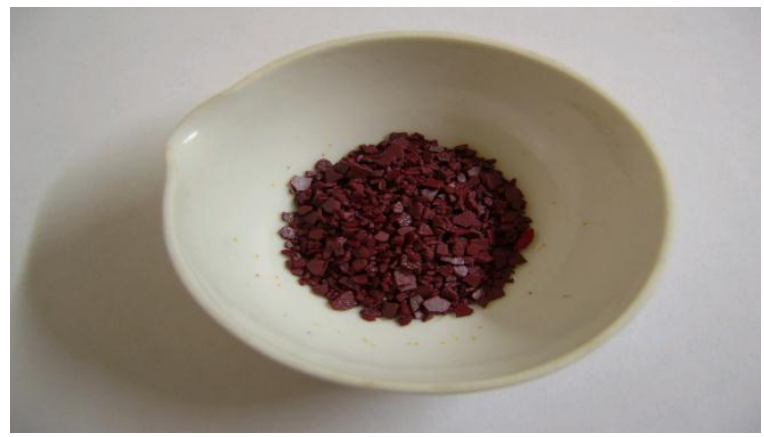

(b)

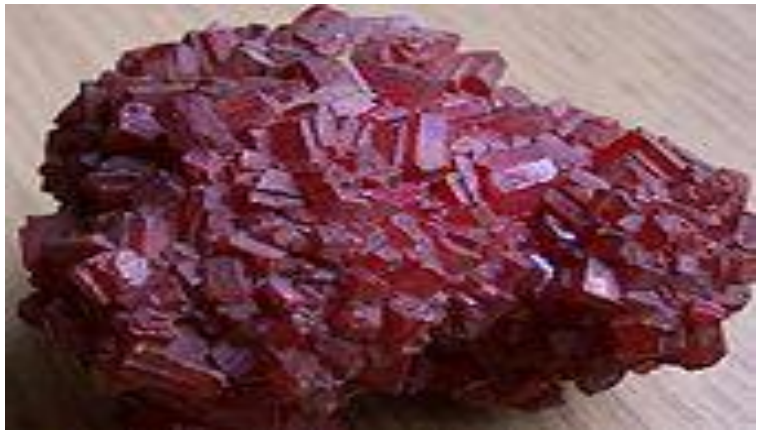

(c)

Fig. 1. Chromium compounds - a) Chromit ore; b) chromium (VI) oxide; c) chromate mineral Lopezite

\subsection{EUROPEAN LEGISLATIVE REQUIREMENTS}

In the early 2005 this Directive was registered as a national regulation of all EU members. At the same time CEN/TC51 Technical Committee has prepared a draft European standard (PrEN 196-10: 2004) for the determination of water soluble chromium (VI) in cement [12].

$\mathrm{Cr}(\mathrm{VI})$ cannot be removed from the raw cement economically, but must be reduced to $\mathrm{Cr}$ (III). In order to fulfill the strict directive limitations of $2 \mathrm{ppm}$ water soluble chromium (VI) the cement producers are obliged to add reducing agents such as ferrous sulfate, ammonium ferrous sulfate, manganese sulfate etc. Furthermore, the producers must provide information on safe shelf life [13]. Due to the manner and form chosen by most cement producers for adding reducing agents, the monitoring of chromium (VI) led to different analytic results; the $2 \mathrm{ppm}$ limit value for chromium (VI) is often exceeded. 
For the reasons mentioned above, the monitoring of hexavalent chromium is of great importance in order to preserve the human health and to ensure minimal environmental impact.

Several analytical instrument techniques can be employed for the determination of this hazardous substance such as spectrophotometry [14,15], ion chromatography [16], pulse chromatography [17], by the use of HPLC-ICP-MS, FPLC-ETAAS, and selective extraction techniques [15], but the most applied in routine analysis is determination by UV- Vis spectrophotometry [14,15]. The determination of hexavalent chromium in cement related material extracts is frequently monitored in cement industries to comply with the European Directive that limits the use of cements containing $2 \mathrm{mgkg}^{-1}$ of chromium [18].

It was found that the leachability of the soil stabilized by cement was high in some cases, and the amount of $\mathrm{Cr}(\mathrm{VI})$ leached was larger than could be accounted for by the "soluble $\mathrm{Cr}(\mathrm{VI}) "$ in the cement as determined by the standard method [8]. The new Guidance on the application of this European standard ((PrEN 196-10: 2006, Annex B) claims that occasionally the method can be applied without modification but in many other cases it will be necessary to modify the extraction and/or filtration procedure [12].

In this article, various sample preparation procedures, are evaluated for the determination of $\mathrm{Cr}$ (VI) in cement by UVVis absorption spectroscopy based on the German TRGS 613 [13].

For the estimation of the optimal time of extraction different extraction times were applied. In order to reduce the time of the analysis and hence the cost of the analysis, the optimal extraction time was found.

\section{EXPERIMENTAL}

\subsection{REAGENTS AND SOLUTIONS}

All chemicals (Merck, Germany, purity $>99 \%$ ) were of analytical/reagent grade and employed without further purification. Distilled water was used in the preparation of the various solutions.

All solutions were prepared according to the German TRGS 613-standard method [13]. Thus, the stock $\mathrm{K}_{2} \mathrm{Cr}_{2} \mathrm{O}_{7}$ solution of $1 \mathrm{~g} \mathrm{~L}^{-1}$ was prepared by dissolving $2.829 \mathrm{~g}$ of dried potassium bichromate in $1000 \mathrm{~mL}$ of distilled water. The standard solution of $5 \mathrm{mg} \mathrm{L}^{-1} \mathrm{Cr}$ (VI) was prepared as $5 \mathrm{~mL}$ of the stock solution were pipetted into a volumetric flask and diluted with distilled water to $1000 \mathrm{~mL}$. Diphenylcarbazide solution was prepared by dissolving $1 \mathrm{~g}$ of 1,5-diphenylcarbazide (DPC), $\mathrm{CO}\left(\mathrm{NHNHC}_{6} \mathrm{H}_{5}\right)_{2}$, in $100 \mathrm{~mL}$ acetone and acidified with a drop of acetic acid. Hydrochloric acid solution was prepared by mixing of concentrated $\mathrm{HCl}$ with water in a ratio $1: 1$.

\subsection{INSTRUMENTATION}

UV-Vis spectrophotometer (Carry $50 \mathrm{Scan}$, Varian) equipped with a $10 \mathrm{~mm}$ short path length cell was used for absorbance measurements. The spectrophotometer is controlled by Cary WinUV software (Fig. 2).

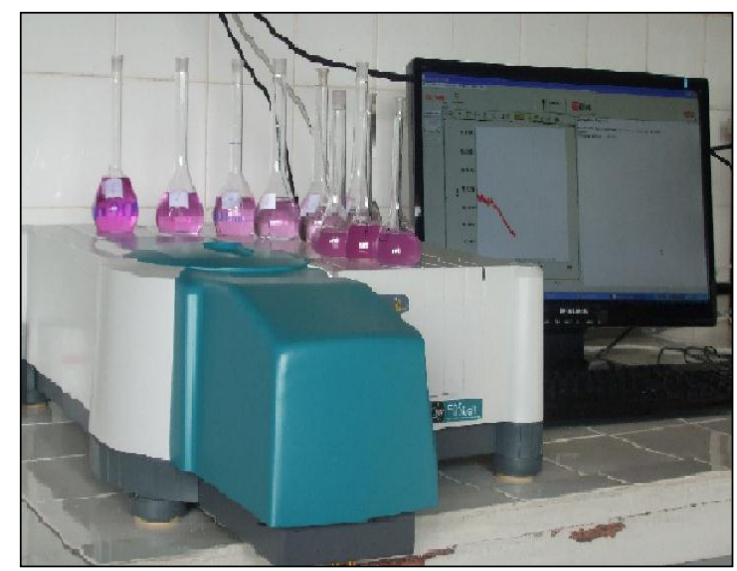

Fig. 2. UV-Vis spectrophotometer (Carry 50 Scan, Varian); standard solutions of $\mathrm{Cr}(\mathrm{VI})$ and extracted $\mathrm{Cr}(\mathrm{VI})$ compexed with diphenylcarbazide 


\subsection{SAMPLE PREPARATION}

The cement samples were prepared using paste extraction method based on TRGS 613. $10.0 \mathrm{~g}$ of cement sample was accurately weighted $( \pm 0.01 \mathrm{~g})$, then $40 \mathrm{~mL}$ of water were added and the mixtures were stirred for 15 min (stirred bar $40 \mathrm{~mm}, 300 \mathrm{rpm}$ ). The suspensions were filtered through $0.45 \mu \mathrm{m}$ filters. Finally $20 \mathrm{~mL}$ were pipetted from the filtrate and were treated for the final preparation.

\subsection{ANALYTICAL PROCEDURE}

The construction of the calibration curve is achieved by measuring the absorption of six standard solutions against blank. Briefly, standard solutions containing 2.5 to $20.0 \mu \mathrm{g} \mathrm{L}^{-1}$ chromium (VI) were prepared as consequently $0.5,1.0,1.5,2.0,3.0$ and 4.0 $\mathrm{mL}$ of chromium standard solution were pipetted into $100 \mathrm{~mL}$ volumetric flasks. The solutions were diluted with approximately 40 $\mathrm{mL}$ of water. Then to each flask, both $2 \mathrm{~mL}$ of hydrochloric acid and $2.0 \mathrm{~mL}$ of the diphenylcarbazide indicator solution were added and diluted to the corresponding volume. The reagents were mixed thoroughly by swirling and the flasks were mixed once again and left for 15 minutes to allow color development. The cement filtrates are treated as to each flask $2 \mathrm{~mL}$ of hydrochloric acid was added, and then $2.0 \mathrm{~mL}$ of the diphenylcarbazide indicator solution were added. The $\mathrm{pH}$ of the solutions should be 1 to 2 ; if no it should be adjusted with hydrochloric acid and diluted to the volume of $100 \mathrm{~mL}$. The absorbance of the solution was measured after $15-30$ minutes. The above procedure was applied to the leachate solutions. The absorbance of the colored solutions has a linear relationship to the chromium (VI) concentration and it is measured at wavelength $540 \mathrm{~nm}$ against the blank.

\subsection{EVALUATION OF THE CONCENTRATION}

The following equation was use for the calculation of the $\mathrm{Cr}(\mathrm{VI})$ concentration:

$C r(V I)_{\text {soluble }}=C V_{1} / M V_{2}, g$

where $\operatorname{Cr}(V I)_{\text {soluble }}$ is the concentration of water soluble hexavalent chromium (ppm), $C$ is the concentration of $\mathrm{Cr}$ (VI) in $\mu g$ in $100 \mathrm{~mL}$ volumetric flask, $V_{I}$ is the volume of water in which the original sample is suspended, $\mathrm{mL}$, $V_{2}$ is the volume of filtrate which is transferred in the volumetric flask, $\mathrm{mL}, M$ is the mass of the cement sample, $g$.

\section{RESULTS AND DISCUSSION}

The analyses are carried out without oxidation process. The performance of the extraction of the hexavalent chromium was achieved by the procedure of TRGS 13. The analytical procedure involves forming a complex that is purple-red in color $(\mathrm{Cr}(\mathrm{VI})$ oxidizes 1,5 diphenylcarbazide to 1,5 diphenylcarbazone) [12].

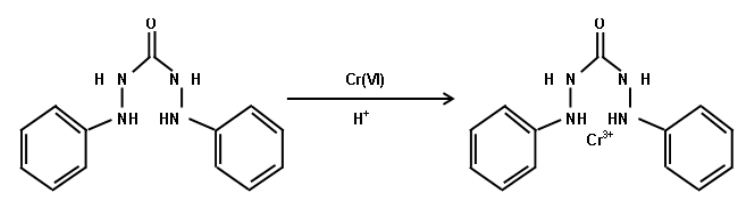

It is necessary to remember that this complex forms and is stable only in an acidic environment and for that reason it is envisaged the acidification of the solution containing chromate extracted from the cement. The maximum absorption is at $\lambda_{\max }$ $=540 \mathrm{~nm}$. The change in spectras over the range 190-1100 $\mathrm{nm}$ (Fig. 3) were recorded in two separate experiments using the WinUV Scan.

Spectrophotometric measurement should be made at least 15 but not more than 30 minutes after the addition of reagent to the sample. The amount of radiation absorbed is compared with a previously obtained calibration plot and is related to the metal concentration by the calibration data. 


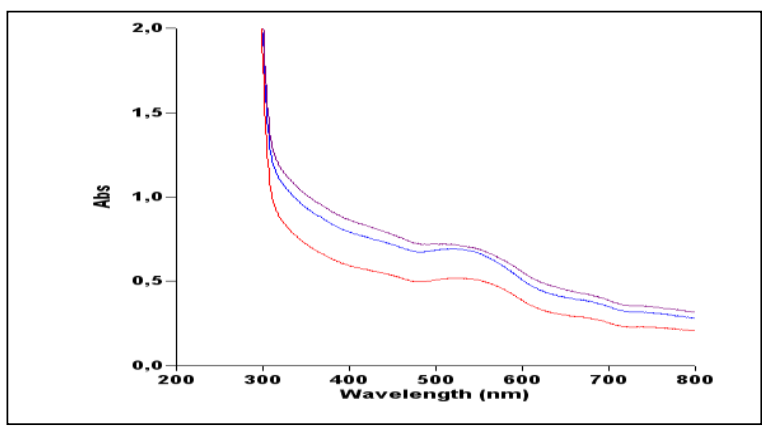

Fig. 3. Scan of extracted chromium complexed with diphenylcarbazide - absorbance versus wavelength

Accuracy depends on the promptness of the analysis. According to the literature detection limit of the method is $3 \mu \mathrm{g} \mathrm{L}^{-1}$, interfering substances - iron, vanadium, and mercury may interfere [19].

Results for the unknown $\mathrm{Cr}(\mathrm{VI})$ in cement extracts determined from using the standards are summarized in Table 1 . The precision (RSD) and relative error is good and the time required to analyze the sample is minimal.

It should be noted that according to the current regulations, the maximum level allowed for content of $\mathrm{Cr}$ (VI) in cement are higher for sample I, VI and VII. However, the levels of hexavalent chromium present in the next seven samples satisfy the European standards.

TABLE. 1: SPECTROPHOTOMETRIC ANALYSES OF CEMENT SAMPLES

\begin{tabular}{|c|c|c|}
\hline $\begin{array}{c}\text { Cement sample } \\
\text { No }\end{array}$ & $\begin{array}{c}\text { Concentration of } \mathrm{Cr}(\mathrm{VI}) \\
\bar{x} \pm \mathrm{tS} / \sqrt{\mathrm{n}},\left(\mathrm{mg} \mathrm{kg}^{-1}\right)\end{array}$ & $\begin{array}{c}\mathrm{RSD} \\
S_{r}=(S / \bar{x}) 100 \\
(\%)\end{array}$ \\
\hline $\mathrm{I}$ & $2.5 \pm 0.2$ & 12.8 \\
\hline II & $1.2 \pm 0.1$ & 9.2 \\
\hline III & $1.1 \pm 0.1$ & 4.0 \\
\hline IV & $1.3 \pm 0.1$ & 4.8 \\
\hline $\mathrm{V}$ & $0.9 \pm 0.1$ & 8.1 \\
\hline VI & $3.0 \pm 0.1$ & 1.1 \\
\hline VII & $2.3 \pm 0.1$ & 2.2 \\
\hline VIII & $1.8 \pm 0.2$ & 6.5 \\
\hline IX & $2.0 \pm 0.1$ & 3.2 \\
\hline $\mathrm{X}$ & $1.6 \pm 0.1$ & 6.1 \\
\hline
\end{tabular}

Number of determination $n, 5 ; t$, Students $t$-value at $95 \%$ probability; $S$, standard deviation; $\bar{x}$, an average.
Cement samples of Devnya producer was taken into the evaluation because it is the largest factory in the country. We accepted the results obtained by the paste extraction method from TRGS 613 as an example (the mixture is agitated at $300 \mathrm{rpm}$ for $15 \mathrm{~min}$.) and compared them against the concentration of hexavalent chromium in the extracts obtained as follows: 1) at constant speed of stirring and time of extraction 5,10,15 and 20 minutes respectively, and 2) at speeds of $500,400,300 \mathrm{rpm}$ and time of extraction 10, 12.5 and 15 minutes respectively.

As it can be seen from the Table. 2, the cement extracts of samples I and II showed poor recovery, especially for I sample. The accuracy for sample II was poor but the precision and repeatability were good.

The results in Table. 2 and Fig. 4 indicate that the amount of $\mathrm{Cr}(\mathrm{VI})$ extracted strongly depends on the extraction time at constant speed of the rotary.

TABLE. 2: DETERMINATION OF CR(VI) OF THE FILTERED EXTRACTS USING DIFFERENT EXTRACTION TIME

\begin{tabular}{|l|l|l|l|}
\hline $\begin{array}{c}\text { Cement } \\
\text { sample No }\end{array}$ & $\begin{array}{c}\text { Concentration of Cr } \\
(\mathrm{VI}), \\
x \pm \mathrm{tS} / \mathrm{V}_{\mathrm{n},\left(\mathrm{mg} \mathrm{kg}^{-1}\right)}\end{array}$ & $\begin{array}{c}\text { RSD } \\
S_{r}=(S / \bar{x}) 100,(\%)\end{array}$ & $\begin{array}{c}\text { Recovery } \\
(\%)\end{array}$ \\
\hline $\begin{array}{l}\text { I. } 5 \mathrm{~min}, \\
\text { 300rpm }\end{array}$ & $0.584 \pm 0.009$ & 2.86 & 78.92 \\
\hline $\begin{array}{l}\text { II. } 10 \mathrm{~min}, \\
\text { 300rpm }\end{array}$ & $0.616 \pm 0.039$ & 11.79 & 83.24 \\
\hline $\begin{array}{l}\text { III. } 15 \mathrm{~min}, \\
\text { 300rpm }\end{array}$ & $0.74 \pm 0.013$ & 3.31 & 100 \\
\hline $\begin{array}{l}\text { IV. } 20 \mathrm{~min}, \\
\text { 300rpm }\end{array}$ & $0.748 \pm 0.012$ & 3.05 & 101.08 \\
\hline
\end{tabular}

Number of determination $n, 5 ; t$, Students $t$-value at $95 \%$ probability; $S$, standard deviation; $\bar{x}$, an average. 


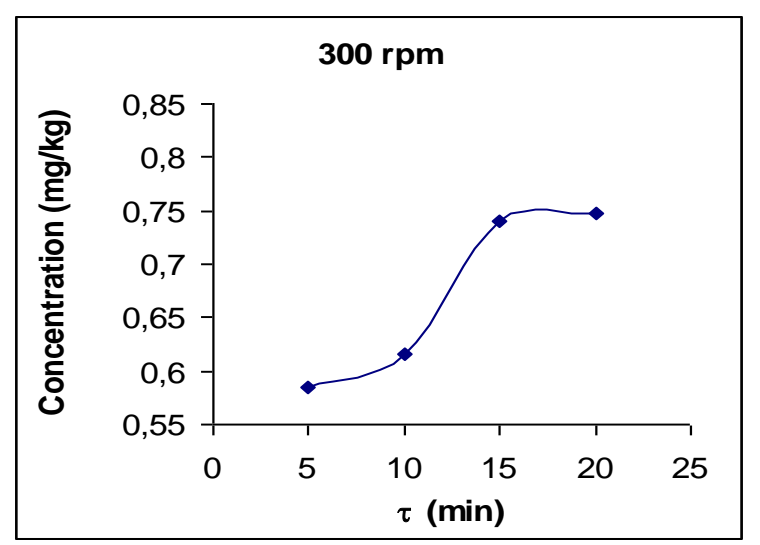

Fig. 4. Dependence of the $\mathrm{Cr}(\mathrm{VI})$ concentration on the time of the extraction at constant rpm

In order to reduce the time for the analysis it was carried out research on the procedure for the extraction of chromium (VI). The curve of Fig. 5 shows that the amount of the $\mathrm{Cr}(\mathrm{VI})$ in the extracts increases with the period of extraction.

Table 2 shows that the recovery was lower with lower time of extraction at $300 \mathrm{rpm}$ but the recoveries of sample II and sample III in Table. 3 are very good. Therefore the procedures of chromium (VI) extraction at $12.5 \mathrm{~min}$ and $400 \mathrm{rpm}$ and $10 \mathrm{~min}, 500 \mathrm{rpm}$ can be applied.

TABLE. 3: DETERMINATION OF CR(VI) OF THE FILTERED EXTRACTS USING DIFFERENT EXTRACTION TIME AND REVOLUTIONS PER MINUTE

\begin{tabular}{|c|c|c|c|}
\hline $\begin{array}{c}\text { Cement } \\
\text { sample No }\end{array}$ & $\begin{array}{l}\text { Concentration of } \\
\qquad \mathrm{Cr}(\mathrm{VI}), \\
\bar{x} \pm \mathrm{tS} / \sqrt{\mathrm{n}},(\mathrm{mg} \\
\left.\mathrm{kg}^{-1}\right)\end{array}$ & $\begin{array}{c}\text { RSD } \\
S_{r}=(S / \bar{x}) \\
100,(\%)\end{array}$ & $\begin{array}{c}\text { Recovery, } \\
\text { (\%) }\end{array}$ \\
\hline $\begin{array}{c}\text { I. } 15 \mathrm{~min}, 300 \\
\mathrm{rpm}\end{array}$ & $0.688 \pm 0.012$ & 3.29 & 100 \\
\hline $\begin{array}{l}\text { II. extraction } \\
12.5 \mathrm{~min}, 400 \\
\mathrm{rpm}\end{array}$ & $0.692 \pm 0.041$ & 10.99 & 100.58 \\
\hline $\begin{array}{l}\text { III. extraction } \\
10 \mathrm{~min}, 500 \\
\mathrm{rpm}\end{array}$ & $0.704 \pm 0.009$ & 2.25 & 102.33 \\
\hline
\end{tabular}

Number of determination $n, 5 ; t$, Students $t$-value at $95 \%$ probability; $S$, standard deviation; $\bar{x}$, an average.
The determination of the analyte is carried out by the absorption of radiation at a fixed value of wavelength $(540 \mathrm{~nm})$. The kinetic curve of formation of chromium dyphenilcarbazide complex was registered. The analysis is started after the components are mixed. The kinetic curve shown in Fig. 6 determines the reaction rate.

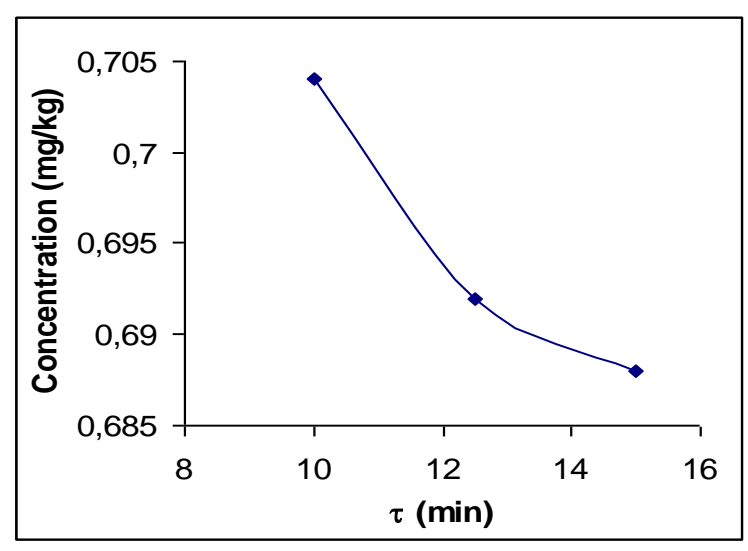

Fig. 5. $\mathrm{Cr}(\mathrm{VI})$ content in extract versus leaching period. Dependence of the $\mathrm{Cr}(\mathrm{VI})$ concentration on the time of the extraction at varying rpm

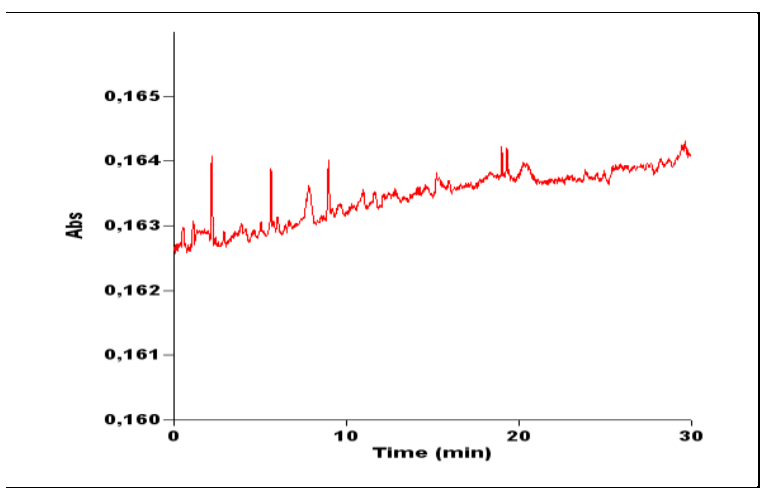

(a)

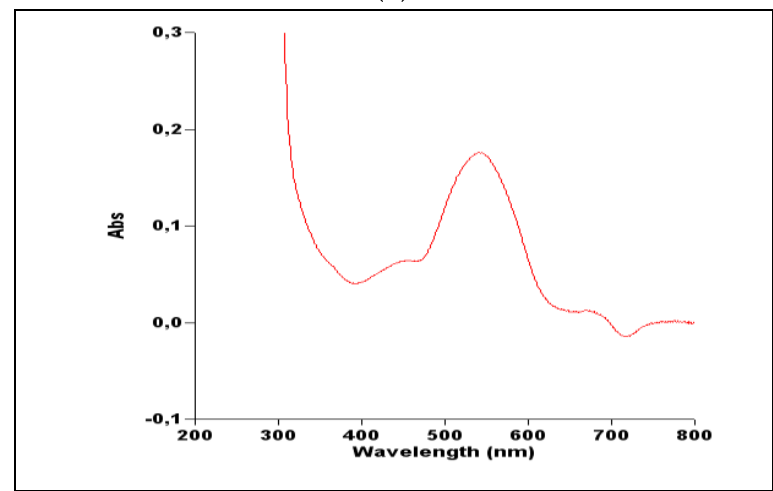

(b)

Fig. 6. a) Kinetic curve of chromium dyphenilcarbazide complexabsorbance versus time in minutes; b) scan of chromium complex (standard 6 with a concentration $200 \mu \mathrm{g} \mathrm{Cr}(\mathrm{VI}) \mathrm{L}^{-1}$ ) - absorbance versus wavelength 
The calibration curve (Fig. 7 a) demonstrate an excellent linearity and reproducibility. Fig. $7 \mathrm{~b}$ shows an overall scan of the standards prepared in the concentration range 25-200 $\mu \mathrm{g} \mathrm{L} \mathrm{L}^{-1}$. The scan of chromium (VI) standards solutions (Fig. 7 b) showed that maximum absorption is not $540 \mathrm{~nm}$ as it is in the standard method. Thus $\lambda_{\max }$ for the standard 6 , standard 5 and standard 4 having concentrations 200, 150 and $100 \mu \mathrm{g} \mathrm{Cr}(\mathrm{VI})$ $\mathrm{L}^{-1}$ ), respectively, is at $538.7 \mathrm{~nm}$. $\lambda_{\max }$ for the standard 3 is at $538 \mathrm{~nm}$ and $\lambda_{\max }$ for standards 2 and $\lambda_{\max }$ for standards 1 are moved toward the shorter wavelengths. Therefore, wavelength maximum $\lambda_{\max }$ is shifted to shorter wavelengths with a decrease in standard solutions concentration.

The innovative Cary WinUV software gives the final results without acquiring additional calculations. The results presented in this work demonstrate an excellent linearity and reproductively for rapid and sensitive measurements of low levels of hexavalent chromium in cement. This simple and costeffective methodology has a potential for cost saving and increasing sample throughput in comparison with other approach such as HPLC-ICP-MS, FPLC-ETAAS and selective extraction techniques in the screening of $\mathrm{Cr}(\mathrm{VI})$.

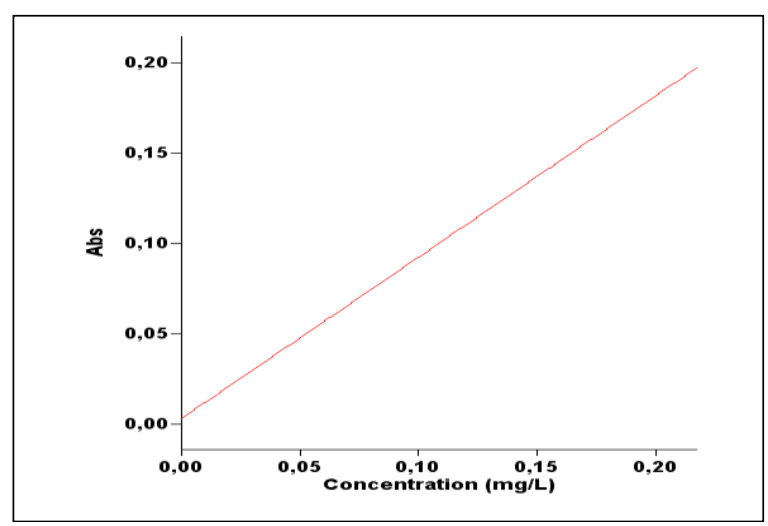

(a)

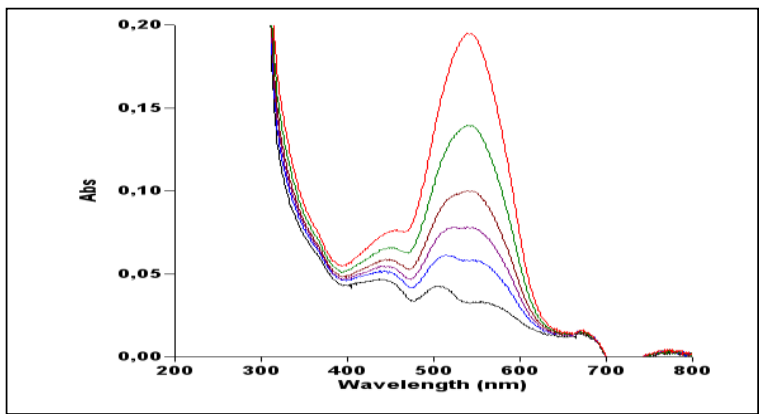

(b)

Fig. 7. a) Calibration curve of the standard $\mathrm{Cr}(\mathrm{VI})$ solutions. R2 $=0.999$. Absorption is measured at $540 \mathrm{~nm}$; b) Absorption spectra of the same chromium (VI) solutions (concentration range $25-200 \mu \mathrm{g}$ $\left.\mathrm{L}^{-1}\right)$

\section{CONCLUSION}

Since the European Community has established rules for implementing the restrictions on the amount of toxic metals such as hexavalent chromium, thus monitoring of chromium (VI) is of great importance for the preservation of human health and to ensure minimal environmental impact.

In the present work 3 out of 10 kinds of cements analyzed did not satisfy the European standard requirements. In this study it was found that the amount of the $\mathrm{Cr}(\mathrm{VI})$ in the extracts increases with the period of extraction. The concentration of $\mathrm{Cr}$ (VI) is dependant from the speed of the rotary. Therefore, in order to reduce the time of the analysis the procedures of chromium (VI) extraction at $12.5 \mathrm{~min}$ and $400 \mathrm{rpm}$ and 10 min, $500 \mathrm{rpm}$ can be applied.

It was found that the wavelength maximum $\lambda_{\max }$ is shifted to shorter wavelengths with a decrease in standard solutions concentration. Thus, the maximum absorbance value at $538.7 \mathrm{~nm}$ was recorded in the range 100$200 \mu \mathrm{g}$ Cr(VI) $\mathrm{L}^{-1}$ ) using Varian Cary 50 reader system. Therefore, for spectrophotometric determination of hexavalent chromium content in cement by the reference method from TRGS 613, the optimal $\lambda_{\max }$ is $538.7 \mathrm{~nm}$. 


\section{ACKNOWLEDGMENT}

The authors wish to extend their sincere appreciation to the Bulgarian Ministry of Education and Science, Fund "Scientific Investigation", for the grant allocation!

\section{REFERENCES}

[1] Lide, D. R., CRS Hand Book of Chemistry and Physics, 74th Edition, SRS Press: USA, p 7440, 1998.

[2] COSHH., The Control of Substances Hazardous to Health (Amendment) Regulations 2004, 2004. http://www.hsedatabases.co.uk/consult/condocs/cd195.htm.

[3] Fernandez, J. A., Monzo, M., Vicent, M., Barba, A. and Palomo, A., Alkaline activation of metakaolin-fly ash mixtures: Obtain of zeoceramics and zeocements. Microporous Mesoporous Materials 108: 41. 2008

[4] Puertas, F., Garcia, D. I., Barba, A., Gazulla, M. F., Palacios, M., Gomez, M. P., MartinezRamirez, S., Ceramic wastes as alternative raw materials for Portland cement clinker production. Cement \& Concrete Composites 30: 798, 2008.

[5] Barceloux, D. G. and Barceloux, D., Chromium. Clinical Toxicology, 37 (2): 173-179, 1999.

[6] Dayan, A. D. and Paine, A, J., Mechanisms of chromium toxicity, carcinogenicity and allergenicity. Review of the literature from 1985 to 2000. Human \& Experimental Toxicology 20 (9): 439, 2001

[7] Potgieter, S. S., Panichev, N., Potgieter, J. H. and Panicheva, S., Determination of hexavalent chromium in

South African cements and cement related materials with electrothermal atomic absorption spectrometry. Cement and Concrete Research, 33: 1589, 2003.

[8] Basketter, D., Horev, L., Slodovnik, D., Merimes, S., Trattner, A. and Ingber, A., Investigation of the threshold for allergic reactivity to chromium". Contact Dermatitis, 44 (2), 70, 2000.

[9] Directive 2003/53/EC (the 26th amendment of the marketing and use of certain dangerous substances and preparations (nonylphenol, nonylphenol ethoxylate and cement).

[10] Leem, J., Lee, E., Kim, H. and Kim, M., The health effect of chromium containing cement dust assessed by combined methods of epidemiologic and toxicologic approach. Epidermiology, 19(6), pS230, 2008

[11] Kristiansen, J., Christensen, J. M. and Byrialsen, K., A DANREF Certified Reference Material for Chromate in Cement. Analyst, 122, 1155, 1997.

[12] Draft prEN 196-10, European standards. methods of testing cements - Part 10: Determination of the water soluble chromium (VI) content in cement, 2005.

[13] Technical Regulation for Hazardous Substances. TRGS 613, issue October 2002

[14] Yamaguchi, O., Ida, M., Uchiyama, Y. and Hanehara, S., A method for the determination of total Cr (VI) in cement. Journal of the European Ceramic Society, 26 (4-5), 785, 2006.

[15] Scancar, J., Milacic, R. and Donard, O. F. X., Determination of hexavalent chromium in cement by the use of HPLC-ICP-MS, FPLCETAAS, spectrophotometry and selective extraction techniques. Journal of Analytical Atomic Spectrometry, 20 (9): 871-875, 2005.

[16] Bravo, A., Cerulli, T., Dragoni, M., Magistri, M. and Padovani, D., Determination of soluble chromates in cement and cement-based materials by ion chromatography. ZKG International, 58 (7), 55-60, 2005

[17] Ghandour, M. A,, Aboul-Kasim, E., Ali, A. M., Belal, A. A. and Soliman, O. A., Determinationof $\mathrm{Cu}(\mathrm{II})$ and $\mathrm{Cr}(\mathrm{VI})$ in cementby differential pulse polarography. ZKG International, 55 (3), 94-99, 2002.

[18] Margui, E., Fontas, C., Toribio, M., Guillem, M., Hidalgo, M. and Queralt, I., Determination of water soluble hexavalent chromium in clinker samples by wavelength dispersive X-ray fluorescence spectrometry after concentration in activated layers. Appl Spectrosc. 64(5), 547- 551, 2010.

[19] Towill, L. E., Reviews of the Environmental Effects of Pollutants: III. Chromium. ORNL/EIS-80 and EPA-600/1-78-023: USA, $p$ $28,1978$. 
التحديد الطيفي لمحتوى الكروم سداسي التكافؤ في عينات الأسمنت التجاري بأستخذام طريقه سهله وسريعه لأستخلاص وتحليل الكروم

\author{
كر اسيمير ا ستانتشيفا1 ، تشاند باشـا2 \\ 1 قسم الكيمياء غير العضوية والتحليلية، جامعة أ.د آسن زلاتاروف، بور غاس ، بلغاريا

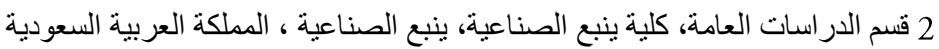

الملخص:

تم أستخدام طريقه سهله وسريعه لأستخر اج وتحليل الكروم بو اسطة طريقة طيفية . في جميع أنحاء العالم محتوى الكروم سداسي التكافؤ في الأسمنت تحت التحكم. في أوروبا، تم فرض قيود جديدة على كمية هذه المادة تحظر استخدام الأسمنت بتو اجده بتركيز أكثر من 2 جزء في المليون. وبالرغم من ذلك ، فأن محتويات الكروم سداسي التكافؤ في الأسمنت فوق 2 مليغر ام / الكيلو غرام وهي لا تز ال موجودة في كثير من الأحيان .

تعتبر هذه الدراسة مساهمة في وضع القيود المحتملة لهذا المركب ـ وأظهرت التحاليل أن 7 من 10 عينات الاسمنت و التى تم تحليلها فى هذه الدراسه تلبى منطلبات قيمة الحد من 2 جزء في المليون الكروم الذائب في الماء في الإسنت المتوفرة في السوق . الكروم سداسى التكافؤ تم تحليله بأستخدام طريقة طيفية . TRGS 613 من diphenylcarbazide أظهرت نتائج أمتصاص الأطياف أن ذروة الامتصاص القصوى لمبلغم الكروم سداسي التكافؤ عند 538.7

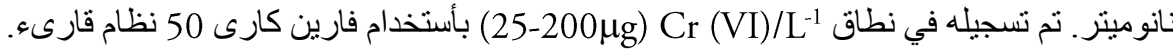
عرضت هذه الدراسه طريقه جديدة لأستخلاص الكروم ـ نم تحديد المعاملات القصوى للمتغيرات مثل وقت الاستخراج في الاعتماد على سرعه التقليب و تباين الطول الموجي وكانت النتائج التي تم الحصول عليها مرضية . فى هذا العمل تم اختبار عينة من (Devnya) وهى الثركة المصنعة، ووجد أن هذا النوع من الأسمنت تلبي منطلبات المعايير الأوروبية ـ أخيراً، يصف هذا التطبيق أبسط وأسرع طريقه لتحليل الإسمنت ومن حيث التكلفة المنخفضة لقياس المستويات من الكروم سداسي التكافؤ. 